\title{
STRATEGI PENGEMBANGAN HASIL HUTAN BUKAN KAYU DI KAWASAN HUTAN LINDUNG GUNUNG SOPUTAN KPHP UNIT V PROVINSI SULAWESI UTARA
}

\author{
Irene Christine Mandang \\ Bobby J. V. Polii \\ Hengki Walangitan
}

\begin{abstract}
This study aims to 1) identify the potential types of NTFPs, 2) analyze the level of excellence, 3) analyze the role and influence of stakeholders and formulate superior NTFP development strategies. This research was carried out from March to July 2018, in the Unit V Gunung Soputan Protection Forest, especially in the HKm area. Tolombukan Satu Village and Liwutung Dua Village, Pasan Sub-district, Southeast Minahasa Regency, North Sulawesi Province. This research uses descriptive method, through field observation, interviews with key informants and desk study. The superior NTFP development strategy is carried out through three phases, namely the analysis of NTFP excellence levels, stakeholder analysis and SWOT analysis to formulate a strategic plan for the development of superior NTFPs. The results showed that the types of NTFPs found in the Mount Soputan HL area, namely pine (Pinus merkusii Jungh et de Virese), sugar palm (Arenga pinnata Merr), bamboo (Bamboo sp.) with class 2 level of excellence and the potential to be used as regional superior products; and candlenut (Aleurites moluccana Wild) with grade 3 excellence. From the analysis, 12 stakeholders were involved in HKm activities consisting of three primary stakeholders and nine secondary stakeholders with categories as Key players, Context setters, Subjects and Crowds. Furthermore, the superior NTFP development strategies that can be carried out are: 1) facilitation (infrastructure assistance, business capital, post-harvest handling and marketing); 2) development of nursery gardens, increase in intensive cultivation and expansion of planting areas of NTFPs; 3) mentoring, counseling, advocacy and training activities; 4) establish mutually beneficial cooperation; 5) accelerating the provision of access to area management to other forest communities. Participation, contribution, involvement and cooperation from parties related to the "joint control" collaboration model is needed to realize NTFP management and development. *eprm*
\end{abstract}

Keywords: superior non-timber forest products (NTFPs), stakeholder roles, development strategies, Southeast Minahasa Regency.

ABSTRAK

Penelitian ini bertujuan untuk 1) mengidentifikasi potensi jenis HHBK, 2) menganalisis tingkat keunggulannya, 3) menganalisis peran dan pengaruh para stakeholder serta merumuskan strategi pengembangan HHBK unggulan. Penelitian ini dilaksanakan dari bulan Maret sampai Juli 2018, di Hutan Lindung (HL) Gunung Soputan KPHP Unit V, khususnya di lokasi areal HKm. Desa Tolombukan Satu dan Desa Liwutung Dua, Kecamatan Pasan, Kabupaten Minahasa Tenggara, Provinsi Sulawesi Utara. Penelitian ini menggunakan metode deskriptif, melalui observasi lapangan, wawancara dengan informan kunci dan desk study. Strategi pengembangan HHBK unggulan dilakukan melalui 3 tahap yaitu analisis tingkat keunggulan HHBK, analisis stakeholder dan analisis SWOT untuk perumusan rencana strategis pengembangan HHBK unggulan. Hasil penelitian menunjukkan bahwa jenis-jenis HHBK yang terdapat di kawasan HL Gunung Soputan, yaitu pinus (Pinus merkusii Jungh et de Virese), aren (Arenga pinnata Merr), bambu (Bamboo sp.) dengan tingkat keunggulan kelas 2 dan berpotensi untuk dijadikan sebagai produk unggulan daerah; dan kemiri (Aleurites moluccana Wild) dengan tingkat keunggulan kelas 3. Dari hasil analisis diperoleh 12 stakeholder yang terlibat dalam kegiatan HKm yang terdiri atas tiga stakeholder primer dan sembilan stakeholder sekunder dengan kategori sebagai Key players, Context setter, Subjects dan Crowd. Selanjutnya strategi pengembangan HHBK unggulan yang dapat dilakukan, yaitu: 1) fasilitasi (bantuan sarana prasarana, modal usaha, penanganan pasca panen dan pemasaran); 2) pembangunan kebun bibit, peningkatan budidaya intensif dan perluasan areal tanam jenis HHBK; 3) kegiatan pendampingan, penyuluhan, advokasi, dan pelatihan; 4) menjalin kerjasama yang saling menguntungkan; 5) percepatan pemberian akses kelola kawasan kepada masyarakat sekitar hutan lainnya. Diperlukan peran serta, kontribusi, keterlibatan dan kerjasama dari pihak terkait dengan model kolaborasi "kontrol bersama" untuk dapat mewujudkan pengelolaan dan pengembangan HHBK.

Kata kunci: hasil hutan bukan kayu unggulan (HHBK), peran stakeholder, strategi pengembangan, Kabupaten Minahasa Tenggara 


\section{PENDAHULUAN}

\section{Latar Belakang}

Hasil Hutan Bukan Kayu (HHBK) merupakan salah satu sumberdaya hutan yang memiliki keunggulan komparatif dan bersinggungan langsung dengan masyarakat sekitar hutan (Departeman Kehutanan, 2010). HHBK secara ekonomis memiliki nilai ekonomi tinggi dan berpeluang untuk meningkatkan pendapatan dan kesejahteraan masyarakat, namun pengembangan usaha dan pemanfaatan HHBK selama ini belum dilakukan secara intensif (Kementerian Kehutanan, 2010). Pemerintah Republik Indonesia telah mengeluarkan kebijakan dalam rangka mengoptimalkan pemanfaatan HHBK diantaranya yaitu Peraturan Menteri Kehutanan (Permenhut) Nomor P.35/Menhut-II/2007 tentang Hasil Hutan Bukan Kayu, Permenhut Nomor P.19/Menhut-II/2009 tentang Strategi Pengembangan Hasil Hutan Bukan Kayu Nasional, dan Permenhut Nomor P.21/Menhut-II/2009 tentang Kriteria dan Indikator Penetapan Jenis Hasil Hutan Bukan Kayu Unggulan (Suhesti dkk, 2017).

Kelompok masyarakat di Desa Tolombukan Satu (Kelompok Tani Soman) dan Desa Liwutung Dua (Kelompok Tani Sinoran) Kecamatan Pasan Kabupaten Minahasa Tenggara diberikan akses untuk mengelola kawasan melalui kegiatan Hutan Kemasyarakatan $(\mathrm{HKm})$. Izin Usaha Pemanfaatan Hutan Kemasyarakatan (IUPHKm) yang nantinya dapat dimanfaatkan oleh masyarakat pada kawasan hutan lindung salah satu diantaranya yaitu pemanfaatan dan pemungutan HHBK. Dengan diketahuinya jenis-jenis HHBK yang berpotensi untuk menjadi komoditas unggulan dalam meningkatkan kesejahteraan masyarakat setempat dan memberikan kontribusi bagi daerah, maka akan dapat disusun strategi pengembangannya sesuai dengan kondisi biofisik, sosial, ekonomi dan budaya daerah tersebut dan selanjutnya usaha budidaya dan pemanfaatannya dapat dilakukan secara lebih terencana, terfokus dan berkelanjutan (Wibowo, 2013).

Sinergitas antar multistakeholder serta penanganan dan pengelolaan sumber daya yang baik diperlukan untuk pengembangan HHBK unggulan yang lestari dan berkelanjutan (Oktadiyani dkk, 2015). Oleh karena itu diperlukan strategi pengembangan HHBK unggulan di kawasan Hutan Lindung (HL) Gunung Soputan yang efektif dengan mengoptimalkan peran serta masyarakat dan/atau stakeholder yang terkait, sehingga dapat memberikan kemakmuran bagi masyarakat secara berkeadilan dan kelestarian fungsi hutan tetap terjaga.

\section{Rumusan Masalah}

Rumusan masalah dalam penelitian ini, yaitu:

1. Apa saja jenis HHBK dan bagaimana tingkat keunggulannya baik di dalam dan di sekitar kawasan Hutan Lindung Gunung Soputan KPHP Unit V?

2. Bagaimana peran dan pengaruh para stakeholders dalam pengembangan HHBK unggulan pada kegiatan HKm di KPHP Unit V?

3. Bagaimana rumusan strategi untuk mengembangkan potensi HHBK unggulan di Blok Pemanfaatan Kawasan Hutan Lindung Gunung Soputan KPHP Unit V?

\section{Tujuan Penelitian}

Tujuan yang ingin dicapai dalam penelitian ini adalah:

1. Mengidentifikasi potensi jenis HHBK dan menganalisa tingkat keunggulannya, baik di dalam dan di sekitar kawasan Hutan Lindung Gunung Soputan KPHP Unit V.

2. Menganalisis peran dan pengaruh para stakeholder dalam pengembangan HHBK unggulan yang terlibat dan terkait dengan kegiatan HKm di KPHP Unit V.

3. Merumuskan strategi pengembangan HHBK unggulan di areal HKm pada Blok Pemanfaatan Kawasan Hutan Lindung Gunung Soputan di KPHP Unit $\mathrm{V}$ dengan menggunakan Analisis SWOT (Strength, Weaknesses, Opportunity, Threats).

\section{Manfaat Penelitian}

Penelitian ini diharapkan sebagai bahan pertimbangan dalam pengambilan keputusan/ kebijakan dan merumuskan konsep komitmen bersama para pihak terkait (stakeholder) terutama berkaitan dengan strategi pengembangan HHBK unggulan pada blok pemanfaatan kawasan Hutan Lindung Gunung Soputan di KPHP Unit V, sehingga dapat meningkatkan kesejahteraan masyarakat dan menjaga kelestarian hutan.

\section{METODE PENELITIAN}

\section{Tempat dan Waktu Penelitian}

Penelitian ini dilaksanakan selama 5 bulan, dari Bulan Maret sampai Juli 2018 di Hutan Lindung Gunung Soputan KPHP Unit V, khususnya di lokasi areal HKm bagi kelompok masyarakat di Desa Tolombukan Satu dan Desa Liwutung Dua, Kecamatan Pasan, Kabupaten Minahasa Tenggara, Provinsi Sulawesi Utara. 


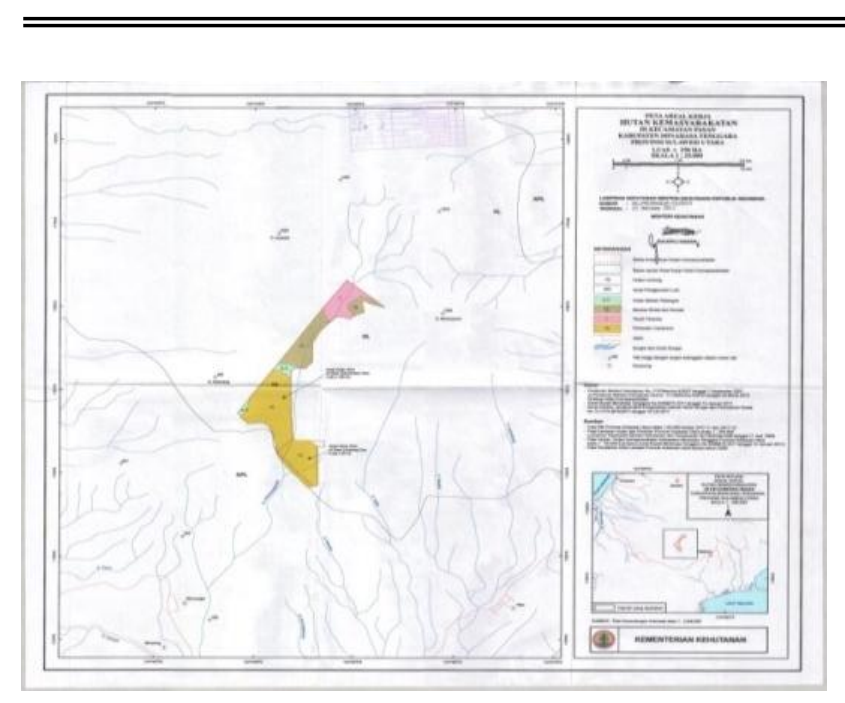

Gambar 1. Peta penetapan areal kerja hutan kemasyarakatan di Hutan Lindung Gunung Soputan

\section{Metode Penelitian dan Teknik Pengumpulan Data}

Metode penelitian yang dipakai adalah deskriptif kualitatif dan kuantitatif dengan teknik survey, wawancara dengan tokoh kunci dan desk study.

Penelitian ini menggunakan data primer dan sekunder. Pengumpulan data primer dilakukan dengan cara pengamatan atau observasi lapangan dan wawancara dengan responden. Sampel tokoh kunci ditentukan secara purposive sampling sebanyak 24 orang, terdiri dari masyarakat yang berhubungan dengan kegiatan pemungutan HHBK dan dinas/instansi/ lembaga terkait dengan kegiatan pengelolaan dan pengembangan HHBK. Teknik wawancara menggunakan instrumen pengumpulan data berupa kuisioner dan matrik kriteria, indikator dan standar penetapan jenis HHBK unggulan sesuai Permenhut No. P.21/Menhut-II/2009.

Pengumpulan data sekunder dilakukan dengan desk study melalui studi pustaka/ literature/data statistik untuk mendukung keperluan analisis penetapan unggulan, analisis stakeholder dan analisis SWOT.

\section{Pengolahan dan Teknik Analisis Data}

1. Penetapan jenis HHBK unggulan

Penetapan tingkat keunggulan suatu jenis HHBK didasarkan pada Permenhut No.P.21 /Menhut-II/2009. Pengolahan dan analisis data yang bersifat kuantitatif dikumpulkan dari lapangan dilakukan dengan menggunakan metode statistik non parametrik (description scoring). (Kementerian Kehutanan, 2010).

\section{Analisis stakeholder}

Pengukuran tingkat kepentingan dan pengaruh stakeholder yang digunakan dalam penelitian ini adalah Metode Baku secara kualitatif dan selanjutnya dilakukan pengolahan data kuantitatif (Manulang, 2018). Analisis stakeholder dilakukan dengan penafsiran matriks kepentingan dan pengaruh stakeholders. Skoring dilakukan terhadap (interest) dan pengaruh (power/influence) setiap stakeholder dengan menggunakan 5 variabel dan 5 indikator untuk masing-masing variabel seperti pada Tabel 1 .

Tabel 1. Penilaian tingkat kepentingan stakeholder

\begin{tabular}{llc}
\hline \multicolumn{1}{c}{ Variabel } & \multicolumn{1}{c}{ Indikator } & Skor \\
\hline Keterlibatan & Terlibat seluruh proses & 5 \\
& Terlibat 3 proses & 4 \\
& Terlibat 2 proses & 3 \\
& Terlibat 1 proses & 2 \\
& Tidak terlibat & 1 \\
\hline Manfaat & Mendapat 4 manfaat & 5 \\
Pengelolaan & Mendapat 3 manfaat & 4 \\
& Mendapat 2 manfaat & 3 \\
& Mendapat 1 manfaat & 2 \\
& Tidak mendapat manfaat & 1 \\
\hline Sumberdaya yang & Menyediakan semua & 5 \\
disediakan & sumberdaya & \\
& Menyediakan 3 & 4 \\
& sumberdaya & \\
& Menyediakan 2 sumberdaya & 3 \\
& Menyediakan 1 sumberdaya & 2 \\
& Tidak menyediakan & 1 \\
& sumberdaya apapun & \\
\hline Prioritas & Sangat menjadi prioritas & 5 \\
Pengelolaan & Prioritas & 4 \\
& Cukup & 3 \\
& Kurang & 2 \\
\hline Ketergantungan & Tidak menjadi prioritas & 1 \\
terhadap & $81-100 \%$ bergantung & 5 \\
sumberdaya & 61 - 80 \% bergantung & 4 \\
& $41-60 \%$ bergantung & 3 \\
& 21 - 40\% bergantung & 2 \\
& $\leq 20 \%$ bergantung & 1 \\
\hline
\end{tabular}

Selanjutnya untuk mengetahui besarnya pengaruh digunakan panduan penilaian untuk mengetahui besarnya pengaruh seperti pada Tabel 2. Jumlah nilai yang didapatkan oleh masingmasing stakeholder adalah 25 poin untuk besarnya kepentingan dan 25 poin untuk besarnya pengaruh (Anonim, 2018 ${ }^{\mathrm{a}}$ ). 
Tabel 2. Penilaian tingkat pengaruh stakeholder

\begin{tabular}{|c|c|c|}
\hline Variabel & Indikator & Skor \\
\hline \multirow{5}{*}{$\begin{array}{l}\text { Aturan/ } \\
\text { kebijakan } \\
\text { pengelolaan }\end{array}$} & Terlibat seluruh proses & 5 \\
\hline & Terlibat 3 proses & 4 \\
\hline & Terlibat 2 proses & 3 \\
\hline & Terlibat 1 proses & 2 \\
\hline & Tidak terlibat & 1 \\
\hline \multirow{5}{*}{$\begin{array}{l}\text { Peran dan } \\
\text { partisipasi }\end{array}$} & Berkontribusi pada semua point & 5 \\
\hline & Berkontribusi dalam 3 point & 4 \\
\hline & Berkontribusi dalam 2 point & 3 \\
\hline & Berkontribusi dalam 1 point & 2 \\
\hline & Tidak Berkontribusi & 1 \\
\hline \multirow{5}{*}{$\begin{array}{l}\text { Kemampuan } \\
\text { dalam } \\
\text { berinteraksi }\end{array}$} & Berinteraksi dalam semua point & 5 \\
\hline & Berinteraksi dalam 3 point & 4 \\
\hline & Berinteraksi dalam 2 point & 3 \\
\hline & Berinteraksi dalam 1 point & 2 \\
\hline & $\begin{array}{l}\text { Tidak melakukan interaksi } \\
\text { apapun }\end{array}$ & 1 \\
\hline \multirow{5}{*}{$\begin{array}{l}\text { Kewenangan } \\
\text { dalam } \\
\text { pengelolaan }\end{array}$} & $\begin{array}{l}\text { Kewenangan dalam semua } \\
\text { proses }\end{array}$ & 5 \\
\hline & Kewenangan dalam 3 proses & 4 \\
\hline & Kewenangan dalam 2 proses & 3 \\
\hline & Kewenangan dalam 1 proses & 2 \\
\hline & Tidak memiliki kewenangan & 1 \\
\hline \multirow{5}{*}{$\begin{array}{l}\text { Kapasitas } \\
\text { sumberdaya } \\
\text { yang } \\
\text { disediakan }\end{array}$} & Semua sumberdaya & 5 \\
\hline & 3 sumberdaya & 4 \\
\hline & 2 sumberdaya & 3 \\
\hline & 1 sumberdaya & 2 \\
\hline & $\begin{array}{l}\text { Tidak menyediakan sumberdaya } \\
\text { apapun }\end{array}$ & 1 \\
\hline
\end{tabular}

Stakeholder kemudian dipetakan ke dalam matriks analisis stakeholder berdasarkan besarnya kepentingan dan pengaruh (Nurfatriani dkk, 2015), seperti pada Gambar 2.

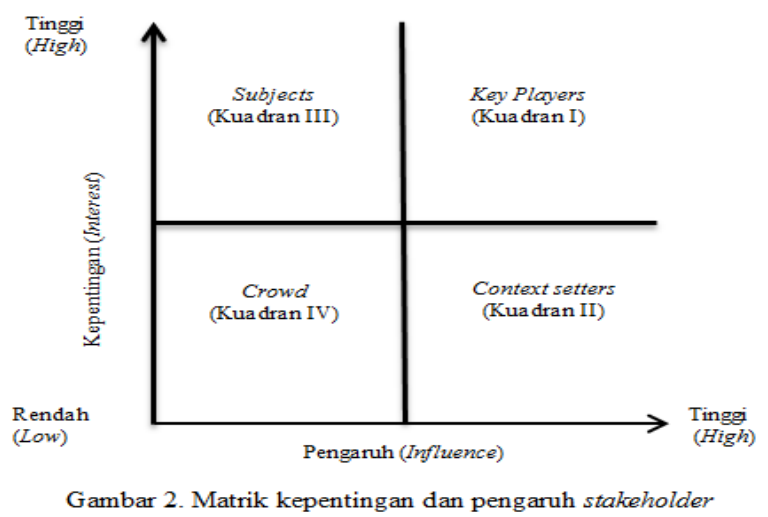

Kuadran I (Key player) merupakan kelompok aktor yang memiliki derajat pengaruh dan kepentingan yang tinggi untuk mensukseskan kegiatan seperti tokoh masyarakat, kepala instansi terkait, dan kepala pemerintahan.

Kuadran II (Context setter) merupakan aktor yang berpengaruh tetapi rendah kepentingannya dalam pencapaian tujuan dan hasil kebijakan.
Kuadran III (Subject) menunjukkan kelompok yang memiliki kepentingan yang tinggi terhadap kegiatan tetapi rendah pengaruhnya, mencakup anggota organisasi yang melakukan kegiatan dan responsif terhadap pelaksanaan kegiatan tetapi bukan pengambil kebijakan.

Kuadran IV (Crowd) mewakili kelompok aktor rendah pengaruh dan kepentingannya, Interest mereka dibutuhkan untuk memastikan dua hal yakni: (a) interest-nya tidak terpengaruh sebaliknya dan (b) kepentingan dan pengaruhnya tidak mengubah keadaan (Anonim, 2018a).

Selanjutnya pengolahan data hasil wawancara dikuantitatifkan dengan mengacu pada pengukuran data berjenjang lima, seperti pada Tabel 3.

Tabel 3. Ukuran kuantitatif terhadap identifikasi dan pemetaan stakeholde

\begin{tabular}{|c|c|c|c|}
\hline Skor & Nilai & Kriteria & Keterangan \\
\hline \multicolumn{4}{|c|}{ Kepentingan Stakeholder } \\
\hline \multirow[t]{2}{*}{5} & $21-25$ & Sangat & Sangat bergantung pada \\
\hline & & Tinggi & keberadaan sumberdaya \\
\hline 4 & $16-20$ & Tinggi & Ketergantungan tinggi pada \\
\hline & & & keberadaan sumberdaya \\
\hline \multirow[t]{2}{*}{3} & $11-15$ & Cukup & Cukup bergantung pada \\
\hline & & & keberadaan sumberdaya \\
\hline \multirow[t]{2}{*}{2} & $6-10$ & Rendah & Ketergantungan pada \\
\hline & & & keberadaan sumberdaya \\
\hline \multirow[t]{2}{*}{1} & $1-5$ & Sangat & Tidak bergantung pada \\
\hline & & Rendah & keberadaan sumberdaya \\
\hline \multicolumn{4}{|c|}{ Pengaruh Stakeholder } \\
\hline \multirow[t]{2}{*}{5} & $21-25$ & Sangat & Sangat mempengaruhi \\
\hline & & Tinggi & pengelolaan sumberdaya \\
\hline 4 & $16-20$ & Tinggi & $\begin{array}{l}\text { Mempengaruhi pengelolaan } \\
\text { sumberdaya }\end{array}$ \\
\hline 3 & $11-15$ & Cukup & $\begin{array}{l}\text { Cukup mempengaruhi } \\
\text { pengelolaan sumberdaya }\end{array}$ \\
\hline 2 & $6-10$ & Rendah & $\begin{array}{l}\text { Kurang mempengaruhi } \\
\text { pengelolaan sumberdaya }\end{array}$ \\
\hline 1 & $1-5$ & $\begin{array}{l}\text { Sangat } \\
\text { Rendah }\end{array}$ & $\begin{array}{l}\text { Tidak mempengaruhi } \\
\text { pengelolaan sumberdaya }\end{array}$ \\
\hline
\end{tabular}

3. Tahapan perencanaan strategis analisis SWOT SWOT yaitu singkatan dari strength (kekuatan), weaknesses (kelemahan), opportunities (peluang), dan threats (ancaman), sebagai suatu model dalam menganalisis suatu organisasi yang berorientasi profit dan non profit dengan tujuan utama untuk mengetahui keadaan organisasi tersebut secara lebih komprehensif (Fahmi, 2016).

Menurut Wibawa (2013) proses penyusunan perencanaan strategis SWOT melalui tiga tahap, yaitu: a) Tahap pengumpulan data; 
Model yang dipakai dalam tahap ini terdiri matriks faktor strategi eksternal (EFAS) dan matriks faktor strategi internal (IFAS); b) Tahap analisis SWOT; yaitu penyusunan matriks SWOT yang dapat menghasilkan empat set kemungkinan alternatif strategis seperti pada Tabel 4; dan c) Tahapan Pengambilan Keputusan.

Tabel 4. Contoh matriks SWOT

\begin{tabular}{|c|c|c|}
\hline $\begin{array}{l}\text { Faktor Eksternal } \\
\text { (EFAS) }\end{array}$ & Strength (S) & Weaknesses (W) \\
\hline $\begin{array}{l}\text { Opportunities }(\mathrm{O}) \\
\text { Menentukan beberapa } \\
\text { faktor peluang eksternal }\end{array}$ & $\begin{array}{l}\text { Strategi (SO) } \\
\text { Menciptakan } \\
\text { situasi yang } \\
\text { menggunakan } \\
\text { kekuatan, } \\
\text { untuk } \\
\text { memanfaatkan } \\
\text { peluang }\end{array}$ & $\begin{array}{l}\text { Strategi (WO) } \\
\text { Meminimalkan } \\
\text { kelemahan } \\
\text { untuk } \\
\text { memanfaatkan } \\
\text { peluang }\end{array}$ \\
\hline $\begin{array}{l}\text { Threats }(\mathrm{T}) \\
\text { Menentukan beberapa } \\
\text { faktor ancaman eksternal }\end{array}$ & $\begin{array}{l}\text { Strategi (ST) } \\
\text { Menggunakan } \\
\text { kekuatan untuk } \\
\text { mengatasi } \\
\text { ancaman }\end{array}$ & $\begin{array}{l}\text { Strategi (WT) } \\
\text { Meminimalkan } \\
\text { kelemahan dan } \\
\text { menghindari } \\
\text { ancaman }\end{array}$ \\
\hline
\end{tabular}

\section{HASIL DAN PEMBAHASAN}

\section{Potensi dan Tingkat Keunggulan Jenis-Jenis HHBK}

1. Identifikasi potensi jenis-jenis HHBK

Berdasarkan hasil pengamatan potensi jenis-jenis HHBK yang telah dilakukan pada areal HKm KTH Soman diperoleh 3 jenis HHBK, yaitu pinus (Pinus merkusii) sebanyak 105 pohon, aren (Arenga pinnata) sebanyak 75 pohon, dan bambu (Bamboo sp.) sebanyak 3 rumpun. Pada areal HKm KTH Sinoran didapatkan 3 jenis HHBK yakni aren (Arenga pinnata) dengan jumlah 85 pohon, bambu (Bamboo sp.) sebanyak 9 rumpun dan kemiri (Aleurites moluccana) sebanyak 6 pohon.

Pinus (Pinus merkusii Jungh et de Vriese) dengan potensi komoditi getah pinus, Aren (Arenga pinnata MERR) dengan potensi komoditi gula cetak atau gula semut dan minuman cap tikus (etanol), Bambu (Bamboosa sp.) dengan potensi komoditi anyaman bambu dan Kemiri (Aleurites moluccana (L.) Wild) dengan potensi komoditi minyak atsiri.
2. Tingkat keunggulan jenis-jenis HHBK

Berdasarkan kriteria dan indikator penetapan jenis HHBK seperti yang telah dijelaskan pada bagian metode di atas, maka diperoleh hasil analisis tingkat keunggulan masing-masing jenis HHBK antara II dan III, seperti yang disajikan pada Tabel 6.

Sesuai dengan Permenhut Nomor P.21/ Menhut-II/2009, maka dari hasil analisis tingkat keunggulan menunjukkan bahwa Total Nilai Unggulan (TNU) jenis HHBK dilokasi penelitian untuk jenis aren, pinus dan bambu termasuk dalam kelompok kelas nilai unggulan 2 (nilai TNU antara 54 - 77) dengan nilai total pinus sebesar 72,67 diikuti aren sebesar 67,72 dan bambu sebesar 63,78. Dengan demikian ketiga jenis tersebut dapat ditetapkan sebagai jenis HHBK unggulan tingkat kabupaten. Sementara jenis kemiri hanya memiliki nilai unggulan sebesar 51,78 atau termasuk kelompok kelas nilai unggulan 3 (nilai TNU antara 30 - 53) atau tidak unggul.

Tabel 5. Perbandingan nilai indikator dan kriteria jenis-jenis HHBK

\begin{tabular}{|c|c|c|c|c|}
\hline \multirow[t]{2}{*}{ Kriteria /Indikator } & \multicolumn{4}{|c|}{ Jenis-jenis HHBK } \\
\hline & Aren & Pinus & Bambu & Kemiri \\
\hline \multicolumn{5}{|c|}{ Ekonomi (Bobot 35\%; jumlah indikator 7) } \\
\hline Jumlah Nilai indikator & 11 & 17 & 13 & 7 \\
\hline Jumlah NIT & 18,33 & 28,33 & 21,67 & 11,67 \\
\hline \multicolumn{5}{|c|}{ Biofisik dan Lingkungan (Bobot 15\%; jumlah indikator 5) } \\
\hline Jumlah Nilai indikator & 13 & 11 & 11 & 9 \\
\hline Jumlah NIT & 13 & 11 & 11 & 9 \\
\hline \multicolumn{5}{|c|}{ Kelembagaan (Bobot 20\%; jumlah indikator 6) } \\
\hline Jumlah Nilai indikator & 14 & 12 & 10 & 10 \\
\hline Jumlah NIT & 15,55 & 13,32 & 11,11 & 11,11 \\
\hline \multicolumn{5}{|c|}{ Sosial (Bobot 15\%; jumlah indikator 2) } \\
\hline Jumlah Nilai indikator & 4 & 4 & 4 & 4 \\
\hline Jumlah NIT & 10 & 10 & 10 & 10 \\
\hline \multicolumn{5}{|c|}{ Teknologi (Bobot 15\%; jumlah indikator 2) } \\
\hline Jumlah Nilai indikator & 5 & 4 & 4 & 4 \\
\hline Jumlah NIT & 12,5 & 10 & 10 & 0 \\
\hline $\begin{array}{l}\text { Total Nilai Unggulan } \\
\text { (TNU) }\end{array}$ & 69,38 & 72,67 & 83,78 & 51,78 \\
\hline $\begin{array}{l}\text { Nilai Unggulan (NU) } \\
\text { HHBK }\end{array}$ & II & II & II & III \\
\hline
\end{tabular}

Penilaian tingkat keunggulan ini terlihat berbeda bagi kedua kelompok HKm baik KTH Soman Desa Tolombukan Satu maupun KTH Sinoran Desa Liwutung Dua.

Pada areal HKm KTH Soman dapat dikatakan memiliki 3 jenis HHBK unggulan, yaitu pinus, aren dan bambu, sementara dimana pada areal HKm KTH Sinoran hanya memiliki 2 jenis unggulan yaitu aren dan bambu. 
Keunggulan jenis HHBK pinus, aren dan bambu di areal $\mathrm{HKm}$ dari segi ekonomi didukung oleh potensi pasar internasional, lingkup pemasaran, cakupan pengusahaan dan mata rantai yang tinggi, selain itu dari segi biofisik dan lingkungan, memiliki aspek konservasi dan tingkat aksesibilitas yang tinggi. Sementara dari segi sosial didukung oleh peran institusi, telah memiliki standard komoditi dan jumlah kelompok usaha ke tiga jenis ini juga termasuk dalam kategori tinggi. Secara sosial, kepemilikan usaha termasuk kategori tinggi, sebab kelompok merupakan pemegang IUPHKm, dan dari segi teknologi secara umum masyarakat cukup menguasai teknologi budidaya, namun dalam penerapannya terkendala dengan kurangnya ketersediaan bibit unggul, terbatasnya sarana prasarana pembibitan dan pengolahan serta ketidakmampuan modal atau biaya usaha.

Kelemahan untuk semua HHBK adalah aspek kelembagaan, yaitu belum adanya asosiasi kelompok usaha, sehingga belum ada upaya untuk meningkatkan daya saing usaha HHBK. Selain itu belum tersedianya sarana atau fasilitas pengembangan baik di tingkat desa, kecamatan dan kabupaten. Hal ini menunjukkan bahwa perhatian dan dukungan dari pemerintah daerah belum optimal dalam mengembangkan potensi HHBK. Secara biofisik dan lingkungan, ke empat jenis ini belum dilakukan upaya budidaya HHBK selain dari tegakan alam, hal ini menyebabkan kurangnya jaminan keberlangsungan produksi dan tingginya tekanan terhadap tegakan alam. Selanjutnya dari aspek sosial, masih kurangnya minat masyarakat untuk memanfaatkan atau mengusahakan komoditas HHBK untuk sumber penghasilannya. Sementara data mengenai nilai perdagangan ekspor dan lokal untuk ke tiga komoditas HHBK yaitu pinus, kemiri dan bambu, masih sangat kurang baik di tingkat kabupaten maupun provinsi, selain itu keberadaan komoditi getah pinus masih pada tahap awal dan merupakan komoditi baru di Provinsi Sulawesi Utara.

Minimnya data nilai pergadangan HHBK ini sesuai dengan yang dikemukakan oleh Wiratno (2014), bahwa permasalahan yang dihadapi dalam pemanfaatan HHBK diantaranya adalah kebijakan pengembangan HHBK tidak dilakukan secara terpadu dan cenderung parsial serta data produksi HHBK belum tersedia secara valid dan memadai. Lebih lanjut Wahyudi (2013) menyatakan bahwa hal tersebut disebabkan karena sebagian besar komoditas HHBK diperdagangkan dalam skala kecil, bersifat lokal, dan bahkan bersifat barter pada beberapa daerah dan kondisi tertentu.

Peningkatan keunggulan suatu jenis HHBK dapat diupayakan bersama oleh seluruh pihak sehingga tujuan untuk meningkatkan kesejahteraan masyarakat dapat tercapai. Oleh karena untuk mencapai hasil yang maksimal dalam pengembangan HHBK sangat penting untuk melibatkan peran berbagai pihak (stakeholder).

\section{Peran dan Pengaruh Stakeholder dalam Pengembangan HHBK Unggulan}

Berdasarkan hasil wawancara dengan tokoh kunci, para pihak (stakeholders) yang terkait dan terlibat dalam pengembangan HHBK unggulan melalui kegiatan $\mathrm{HKm}$ di KPHP Unit V terdiri dari stakeholder primer, yaitu KPHP Unit V, KTH pemegang IUPHKm, masyarakat sekitar kawasan dan stakeholders sekunder, yaitu Dinas Kehutanan Daerah (Dishutda) Provinsi Sulawesi Utara, Kelompok Kerja Percepatan Perhutanan Sosial (Pokja PPS), Balai Perhutanan Sosial dan Kemitraan Lingkungan (BPSKL) Wilayah Sulawesi, pemerintah desa/kecamatan, Pemerintah Kabupaten Minahasa Tenggara (Dinas Koperasi, UMKM dan Pasar), akademisi dalam hal ini Universitas Sam Ratulangi sebagai lembaga penelitian, dan investor atau pengusaha, termasuk di dalamnya pelaku usaha.

Sesuai hasil wawancara dan analisis yang telah dilakukan terhadap tingkat kepentingan dan kekuatan pengaruh stakeholder, maka berdasarkan besarnya nilai kepentingan dan pengaruh masing-masing stakeholder tersebut, kemudian dipetakan ke dalam matriks kepentingan dan pengaruh stakeholder, seperti pada Gambar 3. 


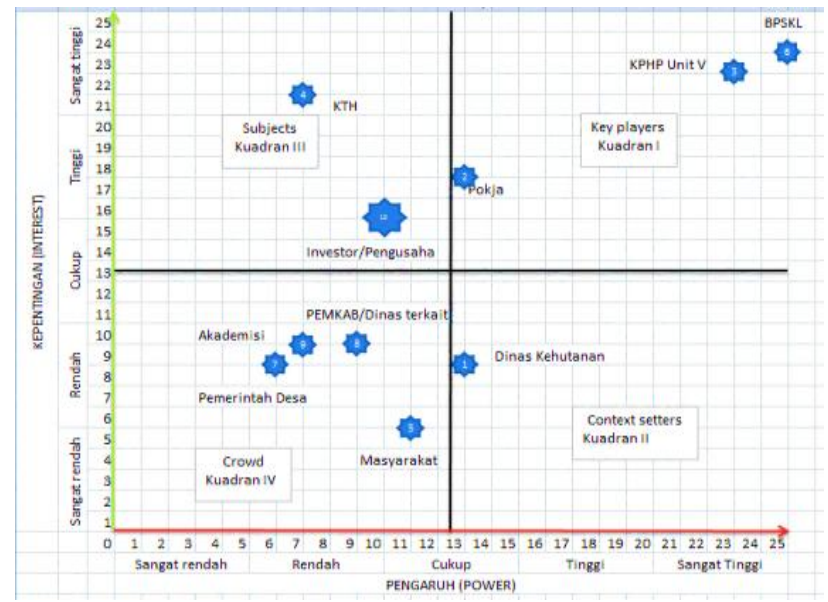

Gambar 3. Peta kepentingan dan pengaruh stakeholder dalam pengembangan HHBK Unggulan di KPHP Unit V.

Gambar 3 menunjukkan hasil pemetaan stakeholder dalam pengelolaan dan pengembangan HHBK unggulan KPHP Unit V, yang dikelompokkan dalam empat kategori yaitu:

Key Players (Kuadran I); yakni stakeholder dengan tingkat kepentingan (interest) dan pengaruh (influence) yang tinggi. Stakeholder ini harus lebih aktif dilibatkan secara penuh untuk mensukseskan kegiatan (Anonim, 2018 ${ }^{\mathrm{a}}$ ) termasuk dalam mengevaluasi strategi baru (Kadir dkk, 2013). Stakeholder yang diklasifikasikan sebagai key players dalam penelitian ini adalah BPSKL Wilayah Sulawesi, KPHP Unit V dan Pokja PPS.

Subjects (Kuadran III); yakni stakeholder dengan tingkat kepentingan (interest) yang tinggi terhadap kegiatan tetapi memiliki pengaruh (influence) yang rendah. Kelompok stakeholder ini mencakup anggota organisasi yang melakukan kegiatan dan responsif terhadap pelaksanaan kegiatan tetapi bukan pengambil kebijakan (Anonim, 2018 ). Stakeholder ini memiliki kapasitas yang rendah dalam pencapaian tujuan, akan tetapi dapat menjadi pihak yang berpengaruh dengan membentuk aliansi dengan stakeholder lainnya. Stakeholder ini sering bisa sangat membantu sehingga hubungan dengan stakeholder ini harus tetap dijaga dengan baik dan sedapat mungkin dapat berkontribusi sesuai dengan kepentingan/manfaat yang diperoleh (Kadir dkk, 2013).
Hal ini diperkuat dengan hasil penelitian yang dilakukan oleh Sembiring dkk (2010) dimana jika posisi stakeholder sebagai subjects maka perlu dilakukan pemberdayaan terhadap stakeholder tersebut. Jika tidak diberdayakan, besar kemungkinan mereka melakukan perlawanan dengan membentuk aliansi dan pada saaatnya akan berada pada key players tetapi terjadi konflik dalam proses tersebut. Stakeholder yang diklasifikasikan sebagai subjects dalam penelitian ini adalah KTH pemegang IUPHKm dan Investor (Pengusaha).

Crowd (Kuadran IV); yaitu Stakeholder dengan tingkat kepentingan (interest) dan pengaruh (influence) yang rendah. Interest mereka dibutuhkan untuk memastikan dua hal yakni (a) interestnya tidak terpengaruh sebaliknya, dan (b) kepentingan dan pengaruhnya tidak mengubah keadaan (Anonim, 2018 ${ }^{\mathrm{a}}$ ). Diperlukan sedikit pertimbangan untuk melibatkan stakeholder ini lebih jauh karena kepentingan dan pengaruh yang dimiliki biasanya berubah seiring berjalannya waktu. Stakeholder ini harus tetap dimonitor dan dijalin komunikasi dengan baik (Kadir dkk, 2013). Stakeholder yang diklasifikasikan sebagai crowd dalam penelitian ini adalah pemerintah desa/kecamatan, pemerintah kabupaten (dinas terkait), masyarakat sekitar dan pihak akademisi (perguruan tinggi).

Context setters (Kuadran II); yakni Stakeholder dengan tingkat kepentingan (interest) yang rendah tetapi memiliki pengaruh (influence/power) yang tinggi diklasifikasikan sebagai Context setters merupakan aktor yang berpengaruh tetapi rendah kepentingannya dalam pencapaian tujuan dan hasil kebijakan (Anonim, 2018 ${ }^{\mathrm{a}}$ ). Stakeholder ini dapat mendatangkan resiko sehingga keberadaannya perlu dipantau dan dikelola dengan baik. Stakeholder ini relatif pasif, akan tetapi dapat berubah menjadi key players karena suatu peristiwa. Hubungan baik dengan stakeholder ini terus dibina dengan tetap harus memberikan informasi yang dibutuhkan, sehingga mereka dapat terus berperan aktif dalam pencapaian tujuan (Kadir dkk, 2013). Stakeholder yang diklasifikasikan sebagai context setters dalam penelitian ini yaitu Dishutda. 
Menurut Nurfatriani dkk (2015), matriks kepentingan dan pengaruh stakeholder atau pemangku kepentingan bersifat dinamis. Matriks ini dapat membantu menentukan kepentingan dan pengaruh dari pemangku kepentingan mana yang harus dipertimbangkan dan dijadikan bahan untuk merumuskan strategi dalam mengatasi masalah atau isu yang terjadi. Selain itu matriks ini dapat menyoroti kerjasama yang perlu diperkuat atau justru diperlemah, perilaku apa yang harus dijaga, menyediakan informasi untuk meyakinkan para pihak untuk mengubah pandangannya.

Menurut Manullang (2018) untuk membantu mengelola stakeholder dapat menggunakan Prinsip-prinsip Clarkson, yaitu: a) Mengakui dan secara aktif memantau kepedulian (masalah, kepentingan) dari semua stakeholder yang sah dan seharusnya memperhitungkan kepentingan-kepentingan mereka secara memadai dalam pengambilan keputusan; b) Berkomunikasi secara terbuka dengan para stakeholder serta mendengarkan dengan baik tentang kepedulian dan kontribusi mereka, dan tentang resiko-resiko yang akan dihadapi karena keterlibatan mereka; c) Menerapkan proses-proses dan cara berperilaku yang sensitif terhadap kepedulian serta kemampuan dari setiap kelompok stakeholder; d) Mengakui saling ketergantungan dan berusaha untuk mencapai distribusi yang adil atas manfaat dan beban di antara stakeholder dengan mempertimbangkan resiko dan kerentanan masing-masing; e) Bekerja sama (secara kooperatif) dengan entitas lain untuk memastikan bahwa resiko dan bahaya yang timbul dapat diminimalkan serta adanya kompensasi yang memadai; f) Menghindari kegiatan yang membahayakan hak asasi manusia yang sangat penting (misalnya hak untuk hidup) atau menimbulkan resiko yang tidak dapat diterima stakeholder lainnya; g) Mengakui adanya potensi konflik akibat adanya peran dan tanggung-jawab hukum dan moral bagi stakeholder dan mengatasinya melalui komunikasi yang terbuka, pelaporan yang tepat, sistem insentif dan bila perlu melibatkan pihak ketiga.

Pengelolaan HHBK di areal HKm pada blok pemanfaatan kawasan Hutan Lindung Gunung Soputan melibatkan peran serta dari banyak pihak, baik secara langsung maupun tidak langsung. Oleh sebab itu hubungan baik di antara stakeholders ini perlu terus dijaga dan dibina dengan menggunakan ke tujuh prinsip di atas. Dari hasil analisis stakeholder dapat dirumuskan strategi manajemen stakeholder dalam mengakomodir pengelolaan dan pengembangan HHBK unggulan di KPHP Unit V diantaranya sebagai berikut: Key players: BPSKL Wilayah Sulawesi, KPHP Unit V dan Pokja PPS.

Ketiga stakeholders ini termasuk dalam Key players dan memiliki nilai prioritas kepentingan dan pengaruh Stakeholder yang sangat tinggi. Hal ini disebabkan karena institusiinstitusi tersebut merupakan regulator sekaligus juga implementator, fasilitator dan evaluator sehingga dapat berpengaruh terhadap terwujudnya pengembangan HHBK.

Menurut Nurfatriani dkk (2015) Key players dapat mempengaruhi tersusunnya kebijakan pengembangan HHBK unggulan dari sumberdaya modal yang dimiliki melalui penetapan anggaran yang mendukung ke arah pengembangan HHBK, kewenangan dalam menyusun rencana pengelolaan HHBK unggulan dan fasilitasi terkait dengan pendampingan, penyuluhan dan pengembangan kelembagaan dan usaha kelompok masyarakat, penerapan teknologi budidaya dan pengolahan serta pengawasan dalam pengelolaan hutan. Tupoksi dari institusi-institusi tersebut membuat tingkat pengetahuan yang dimiliki key players lebih dalam dibanding stakeholders lainnya.

Tingkat kepentingan KPHP Unit V sebagai key players dalam melakukan pengelolaan kawasan hutan baik hutan produksi maupun hutan lindung yang berada di wilayah KPHP Unit V meliputi kepentingan ekonomi, sosial dan lingkungan sehingga dapat bermanfaat bagi masyarakat sekitar hutan, sekaligus juga menjaga fungsi ekosistem hutan. Oleh sebab itu dalam mengelola kegiatan pemanfaatan dan pemungutan HHBK di tingkat tapak, sangat penting untuk menjaga hubungan dan komunikasi yang baik antara KPHP Unit V dengan BPSKL Wilayah Sulawesi, Pokja PPS dan KTH pemegang ijin serta menjalin kerjasama yang saling menguntungkan dalam mendukung kegiatan dan usaha pengembangan HHBK.

Kelompok Kerja Percepatan Perhutanan Sosial merupakan wadah gabungan para pihak terkait dalam program perhutanan sosial, yang walaupun memiliki tingkat kepentingan yang tinggi atau memiliki ketergantungan tinggi pada keberadaan sumberdaya, namun hanya memiliki tingkat pengaruh yang cukup atau cukup mempengaruhi pengelolaan sumberdaya. Hal ini 
disebabkan karena keberadaan Pokja PPS bukan sebagai suatu institusi dan hanya memainkan peranan sebagai fasilitator namun tidak memiliki kewenangan dalam hal anggaran.

Stakeholder yang termasuk dalam key players harus saling berkoordinasi dan bersinergi dengan efektif dalam pengembangan HHBK unggulan. Dari hasil pengamatan lapangan, kendala yang dihadapi adalah lemahnya tata hubungan di antara institusi terkait seperti kurangnya inisiatif untuk menggali potensi yang ada dan bersama-sama terlibat dalam percepatan perhutanan sosial untuk mendorong dan memajukan masyarakat dalam berperan aktif mengembangkan potensi HHBK.

Context setters: Dinas Kehutanan Daerah Provinsi Sulawesi Utara

Stakeholder dengan tingkat pengaruh yang cukup untuk mempengaruhi pengelolaan sumberdaya dan memiliki tingkat kepentingan yang rendah dibandingkan dengan key players dalam pengembangan HHBK unggulan di KPHP Unit V berperan sebagai implementator, fasilitator dan regulator di tingkat provinsi dalam mendukung kebijakan nasional pembangunan kehutanan, khususnya Program Perhutanan Sosial. Dishutda dapat memberikan dukungan dalam bentuk kebijakan (kajian identifikasi potensi, penetapan jenis HHBK unggulan dan rencana pengelolaan dan pengembangaan HHBK tingkat provinsi), fasilitasi sarana prasarana pengolahan HHBK, bantuan teknis (penyediaan bibit HHBK unggulan) dan peningkatan kapasitas SDM dan kelembagaan pengelola HHBK melalui pelatihan dan sosialisasi kepada masyarakat untuk pengembangan HHBK. Selain itu juga melakukan pengawasan dan penertiban peredaran HHBK, agar pengelolaan hutan secara lestari dan masyarakat sejahtera dapat terwujud. Dengan demikian perlu strategi untuk menjadikan Dishutda sebagai pemangku kepentingan yang memungkinkan di masa depan untuk dipertimbangkan dalam perumusan kebijakan pengembangan HHBK di tingkat provinsi.

Subjects: KTH pemegang IUPHKm dan Investor.

KTH pemegang IUPHKm sebagai subjects memiliki tingkat kepentingan yang sangat tinggi yaitu stakeholder yang sangat bergantung pada keberadaan sumberdaya, namun memiliki pengaruh yang rendah yakni kurang mempengaruhi pengelolaan sumberdaya. Dari sisi kepentingan, KTH berperan sebagai implementator dalam pengembangan HHBK di areal IUPHKm-nya sangat berkepentingan secara ekonomi agar lebih meningkatkan pendapatan dan kesejahteraan dengan adanya kepastian hukum dalam melaksanakan kewajiban untuk mengelola areal hutan sesuai ijin yang diberikan dengan memanfaatkan dan mengembangkan potensi HHBK melalui kegiatan $\mathrm{HKm}$.

Hal yang perlu ditekankan dalam hubungan KTH dengan key players yaitu bahwa sebagai penerima manfaat, KTH perlu difasilitasi baik secara kelembagaan, teknis dan manajemen usaha oleh pihak KPHP Unit V agar mereka mampu mengelola dengan baik areal IUPHKm. Oleh sebab itu menurut Kusumedi dan Rizal, 2010 diperlukan kerjasama dan kemitraan yang terjalin dengan baik agar terwujud keseimbangan tiga prinsip dasar dari $\mathrm{KPH}$ yaitu economically profitable, socially acceptable dan environmentally sustainable (secara ekonomi, menguntungkan, dapat diterima masyarakat, sedang biodiversity dan sumberdaya serta ekosistem lingkungan hutan tetap lestari.

Investor (pengusaha) juga sebagai subjects dalam pengelolaan HHBK di KPHP Unit V, merupakan stakeholder dengan tingkat kepentingan yang cukup artinya cukup bergantung pada keberadaan sumberdaya, namun termasuk dalam stakeholder dengan tingkat pengaruh (influence) yang rendah artinya kurang mempengaruhi pengelolaan sumberdaya. Sebagaimana KTH, investor selaku pelaku usaha sangat berkepentingan secara ekonomi agar dapat lebih meningkatkan keuntungan perusahaan. Menurut Nurfatriani dkk (2015) subject memiliki kepentingan yang tinggi akan suatu isu dan ingin mempengaruhi perilaku pemangku kepentingan (stakeholder) lain agar dapat mengatasi isu tersebut akan tetapi tidak memiliki dasar kekuatan yang cukup untuk mempengaruhi pembuat kebijakan.

Hubungan antara instansi pemerintah dalam hal ini KPHP Unit V, Dishutda dan Pokja PPS dengan masyarakat dalam hal ini KTH dapat berbentuk kerjasama dan potensi konflik. 
Dengan demikian strategi potensial yang diperlukan adalah mengoptimalkan koalisi, kolaborasi dan kerjasama antara subjects dan key players yang memiliki tingkat kepentingan tinggi. Untuk itu perlu ditingkatkan kerja sama dan kolaborasi yang efektif antara KPHP Unit V, BPSKL Wilayah Sulawesi dan Pokja PPS dalam menunjang program pembangunan kehutanan, khususnya program perhutanan sosial melalui pendekatan berbasis pemberdayaan dan peningkatan akses masyarakat untuk mengelola areal $\mathrm{HKm}$.

Mekanisme fasilitasi pemberian ijin dan pengawasan dalam pemanfaatan HHBK adalah salah satu mekanisme yang dapat menjadi jalan terwujudnya pengelolaan dan pengembangan HHBK unggulan. Hal ini membutuhkan kerjasama yang harmonis antara intansi pemerintah pusat seperti UPT Kementerian LHK (BPSKL Wilayah Sulawesi) dengan pemerintah provinsi yakni Dinas Kehutanan, KPHP Unit V dan Pokja serta pemegang ijin IUPHKm sebagai wajib bayar iuran kehutanan yakni Provinsi Sumber Daya Hutan khususnya HHBK di Hutan Negara.

Crowd: masyarakat di sekitar kawasan, pemdes/ kecamatan, pemkab dan pihak akademisi dari perguruan tinggi.

Masyarakat sekitar hutan termasuk dalam kategori crowd yang memiliki tingkat kepentingan stakeholder cukup bergantung pada keberadaan sumber daya dan tingkat pengaruh yang rendah yakni kurang mempengaruhi pengelolaan sumberdaya.

Pemerintah desa/kecamatan, pemerintah kabupaten (Dinas Koperasi, UMKM dan Pasar) dan akademisi (Perguruan Tinggi) juga merupakan kelompok crowd yaitu stakeholder yang memiliki tingkat kepentingan dan pengaruh yang rendah yakni kurang mempengaruhi pengelolaan sumberdaya.

Menurut Nurfatriani dkk (2015) masyarakat sekitar hutan berperan sebagai penerima manfaat dari pelaksanaan program-program pemerintah khususnya yang bersumber dari dana penerimaan kehutanan. Masyarakat sekitar hutan memiliki kepentingan yang tinggi dari sisi sosial, ekonomi dan lingkungan terhadap hasil hutan. Masyarakat mengharapkan dengan dikeluarkannya kebijakan pemanfaatan HHBK di dalam kawasan secara legal oleh pemerintah maka akan berdampak positif terhadap pemenuhan kebutuhan hidup masyarakat seharihari dari hutan. Nandini (2013) menyatakan bahwa konsep pembangunan hutan berbasis masyarakat merupakan konsep pembangunan hutan yang diharapkan dapat mengakomodir kebutuhan dan kesejahteraan masyarakat di sekitar hutan. Hal penting yang perlu menjadi perhatian terhadap masyarakat sekitar hutan yang melakukan kegiatan pemanfaatan dan pemungutan HHBK, yaitu perlunya kegiatan sosialisasi dan penyuluhan tentang ketentuan dan aturan perundang-undangan yang berlaku, serta menjaga keamanan kawasan hutan lindung dari pihak-pihak yang akan melakukan pengrusakan di dalam kawasan.

Selain itu pihak KPHP Unit V maupun KTH perlu melibatkan dan menggandeng masyarakat yang sudah terlanjur melakukan usaha pemanfaatan dan pemungutan HHBK di areal $\mathrm{HKm}$ dan juga pemberian akses kelola kawasan bagi masyarakat sekitar hutan melalui fasilitasi pemberian ijin oleh pihak Pokja PPS, KPHP Unit V dan BPSKL Wilayah Sulawesi.

Pemerintah desa atau kecamatan menjalankan fungsi kontrol terhadap pelaksanaan pengelolaan HHBK unggulan oleh anggota masyarakat agar dapat berjalan dan berkembang dengan baik untuk peningkatan kesejahteraan masyarakat tanpa mengesampingkan kelestarian hutan. Kusumedi dan Rizal (2010) menyatakan bahwa partisipasi dari semua pihak dalam pengelolaan HHBK memang sangat diharapkan, akan tetapi tidak serta melibatkan semua pemangku kepentingan, karena setiap stakeholder mempunyai tugas pokok dan fungsi masing-masing.

Pemangku kepentingan (stakeholder) lainnya yang merupakan kategori crowd adalah pemerintah kabupaten (seperti Dinas Koperasi, UMKM dan Pasar) selaku stakeholder di tingkat kabupaten berperan dalam mendukung program pemerintah pusat, provinsi dan kabupaten dengan memberikan fasilitasi sarana pengolahan, ijin usaha maupun pengembangan kapasitas kelembagaan kelompok menjadi unit usaha koperasi.

Pemangku kepentingan terakhir pada kategori crowd yaitu pihak akademisi yang juga 
memiliki kepentingan dan pengaruh yang rendah. Perguruan Tinggi sebagai lembaga penelitian memberikan dukungan penelitian dan pengembangan dengan berperan sebagai advokator dan fasilitator agar terwujud pengelolaan HHBK yang lebih mengarah kepada kelestarian hutan, pemanfaatan jasa lingkungan serta konsep pemberdayaan masyarakat.

Keberadaan stakeholder dengan segala peran yang dapat dilakukan serta potensi yang dimilikinya menjadi modal tersendiri bagi pengelolaan dan pengembangan HHBK di KPHP Unit V. Kolaborasi atau kemitraan dengan stakeholder tersebut $\mathrm{di}$ atas dapat menjadi kunci sukses dalam mengatasi setiap permasalahan yang timbul. Dengan berkolaborasi maka keterbatasan yang dimiliki oleh pengelola HHBK seperti keterbatasan dana, sarana prasarana, serta keterbatasan kemampuan sumberdaya manusia dapat diatasi. Pengelolaan kolaborasi atau yang lazim dikenal dengan istilah co-management atau collaborative management menjadi salah satu alternatif dalam mengakomodasi kepentingan, potensi dan peran stakeholder dalam pengelolaan dan pengembangan HHBK (Kadir dkk, 2013). Menurut Sembiring dkk (2010) model kolaborasi yang sebaiknya dikembangkan adalah "kontrol bersama" yang dimulai dari proses-proses negosiasi (melibatkan stakeholders dalam pengambilan keputusan) dan pengembangan kesepakatan.

Beberapa prinsip dan nilai-nilai utama dalam pengelolaan kolaborasi (Kadir dkk, 2013 dan Sembiring, 2010) antara lain mengakui adanya perbedaan nilai-nilai, kepentingan dan kepedulian dalam pengelolaan sumberdaya hutan; terbuka terhadap kemungkinan hadirnya ragam tipe-tipe pengelolaan sumberdaya hutan diluar sesuatu yang sudah dikenal dan ditetapkan dalam peraturan formal; lebih bersifat persuasif daripada pertentangan; komunikasi yang konstruktif untuk mengembangkan pemahaman bersama daripada kritik-kitik negatif serta memperkuat argumen masing-masing pihak; keterbukaan dan pemerataan dalam pengelolaan sumberdaya alam; memungkinkan masyarakat sipil memainkan peranan yang lebih penting dan bertanggung-jawab; menghormati semua proses sebagai hal yang penting dibandingkan orientasi hasil-hasil dalam waktu singkat; belajar dan bekerja melalui revisi-revisi kegiatan yang sedang berjalan dan meningkatkannya dalam pengelolaan sumberdaya hutan.

\section{Perencanaan Strategis Pengembangan HHBK Unggulan}

Berdasarkan data hasil observasi atau pengamatan, wawancara dan desk study yang telah dilakukan untuk menganalisis tingkat keunggulan HHBK berdasarkan kriteria ekonomi, biofisik dan lingkungan, kelembagaan, sosial dan teknologi, maupun untuk menganalisis peran, tingkat pengaruh dan kepentingan stakeholder, maka dilakukan proses perumusan strategi pengembangan HHBK unggulan dengan menggunakan alat analisis SWOT secara lengkap dapat dilihat pada Tabel 7. Berdasarkan kriteria dan indikator penetapan jenis HHBK unggulan, maka dari hasil penelitian ini dirumuskan beberapa strategi pengembangan HHBK unggulan yang dapat diterapkan di KPHP Unit V, yaitu:

1) Aspek Ekonomi: (i) peningkatan kualitas dan diversifikasi produk HHBK;

2) Aspek Biofisik dan Lingkungan: (i) membangun kebun pembibitan HHBK unggulan; (ii) melakukan budidaya tanaman jenis-jenis HHBK secara intensif; dan (3) perluasan areal tanam jenis HHBK unggulan pada lahan-lahan terbuka dan kritis;

3) Aspek Kelembagaan; (i) penguatan dan pembinaan kelembagaan kelompok usaha produsen/koperasi/ asosiasi dalam mengelola HHBK melalui kegiatan penyuluhan, advokasi, penelitian dan pengembangan (ii) Kebijakan dan sanksi tegas bagi pihak yang melakukan pelanggaran (penegakkan hukum) dengan tetap mengutamakan pendekatan persuasif kepada masyarakat agar dapat menjaga, memanfaatkan dan melestarikan hutan sesuai aturan dan ketentuan yang berlaku; (iii) dukungan kebijakan (anggaran), pendampingan (teknis dan manajemen) dan fasilitasi (sarana prasarana, modal usaha, penanganan pasca panen dan pemasaran) secara tepat sasaran dari pemerintah daerah; 
4) Aspek Sosial; (i) membuka kesempatan bagi pelaku usaha untuk berinvestasi dengan kelompok masyarakat melalui kerjasama yang saling menguntungkan; (ii) mendorong peningkatan akses kelola kawasan kepada masyarakat sekitar hutan lainnya melalui Program Perhutanan Sosial agar ada pemerataan;

5) Aspek Teknologi yaitu meningkatkan kualitas dan kapasitas SDM untuk menguasai teknologi budidaya maupun pengolahan HHBK dengan memberikan pelatihan, magang, studi banding, diklat, dan lain-lain.

\section{Strategi pengambilan keputusan (Matriks SWOT)}

Berdasarkan hasil analisis strategi faktor internal dan eksternal menggunakan matriks SWOT pada Tabel 6, dapat diketahui dan dirumuskan beberapa alternatif strategi pengembangan HHBK unggulan yang dapat dilakukan KPHP Unit V yang terdiri dari strategi SO, strategi WO, strategi ST, dan strategi WT, sebagai berikut:

Strategi WO (Strength-Opportunities) menghasilkan 4 alternatif strategi, yaitu:

1) membangun kebun pembibitan HHBK unggulan dan perluasan areal tanam jenis HHBK unggulan pada lahan-lahan terbuka dan kritis, strategi ini perlu dilakukan mengingat KTH pemegang IUPHKm juga mempunyai kewajiban untuk melakukan kegiatan penanaman jenisjenis HHBK, baik untuk konservasi pada lahan hutan yang terbuka dan kritis, sekaligus juga untuk bertujuan untuk menambah jenis dan mengganti tanaman yang sudah mati atau sudah tidak dapat berproduksi lagi (tua) demi kelangsungan produksi HHBK;

2) mendorong peningkatan akses kelola kawasan kepada masyarakat sekitar hutan lainnya melalui Program Perhutanan Sosial agar ada pemerataan, strategi ini sangat baik dilakukan mengingat untuk menghindari terjadinya konflik diantara masyarakat maupun masyarakat dengan pihak KPHP Unit V, perlu melibatkan peran serta masyarakat sekitar hutan untuk dapat mengelola, menjaga, memanfaatkan dan melindungi kawasan hutan;

3) memberikan fasilitasi bantuan pemerintah secara tepat sasaran, strategi ini diperlukan agar bantuan yang diberikan sesuai dengan kebutuhan dan rencana kelompok masyarakat, disertai dengan pendampingan untuk penguasaan pemanfaatan dan pengelolaan sarana prarasara yang akan diberikan;
4) membuka kesempatan bagi pelaku usaha untuk berinvestasi dengan kelompok masyarakat melalui kerjasama yang saling menguntungkan. Strategi ini dianggap penting karena pada saat pengambilan data dan wawancara, kelompok masyarakat pemegang IUPHKm belum memiliki modal awal dan belum mengetahui tujuan pasar hasil produk HHBK. Namun hal yang penting untuk diperhatikan bahwa hendaknya kerjasama antara KTH dan pengusaha nantinya tidak akan menimbulkan kerugian bagi kedua belah pihak, bahkan diharapkan dapat menjadi hubungan kemitraan yang baik dan saling menguntungkan dengan tetap memperhatikan kelestarian sumberdaya HHBK.

Strategi WO (Weaknesses-Opportunity) menghasilkan 4 alternatif, yaitu:

1) membina hubungan kemitraan, kooperasi, dan koordinasi yang baik serta saling memberikan kontribusi yang bermanfaat diantara stakeholder. Strategi ini merupakan strategi yang sangat penting sebab menyangkut kepentingan, keterlibatan, peran, persepsi dan pengaruh stakeholder yang berbeda-beda, sehingga diperlukan suatu hubungan yang berbasis kepercayaan, tanggung-jawab dan keterbukaan, saling menghormati perbedaan nilai-nilai dan dapat beradaptasi dengan kebutuhan dan kepentingan stakeholder lainnya (Kadir dkk, 2013). Menurut Evalia (2015) komitmen dan kerjasama dari semua stakeholder baik pihak pemerintah, masyarakat dan swasta sangat penting untuk mewujudkan pengembangan HHBK unggulan di KPHP Unit V;

2) meningkatkan kualitas dan kuantitas produk HHBK sesuai standar mutu ekspor dan menjaga kestabilan produksi. Stretegi ini juga dianggap penting, sebab menyangkut komersialisasi produk HHBK bagi kelangsungan dan standarisasi mutu produk HHBK yang dihasilkan. Penggunaan sarana prasarana (alat pengolahan) yang masih sangat sederhana dapat berpengaruh terhadap kualitas produk yang tidak memenuhi standar ekspor (Evalia, 2015);

3) Peningkatan kegiatan penyuluhan, komunikasi, advokasi, penelitian dan pengembangan kepada masyarakat sekitar hutan dengan pendekatan persuasif untuk menjaga, memanfaatkan dan melestarikan hutan. Strategi ini tidak kalah penting dalam mewujudkan pengelolaan dan pengembangan HHBK, sebab tujuan yang ingin dicapai adalah pengelolaan hutan yang lestari dan masyarakat sejahtera dengan menggunakan pendekatan berbasis pemberdayaan dan peningkatan akses masyarakat; dan 
4) adanya dukungan kebijakan (anggaran), pendampingan (teknis dan manajemen) dan fasilitasi (sarana prasarana) dari pihak pemerintah daerah. Perhatian dan kepedulian pemerintah pusat melalui Kementerian Lingkungan Hidup dan Kehutanan (2017), dengan mengeluarkan kebijakan Program Perhutanan Sosial yang memberikan akses kepada masyarakat untuk mengelola dan memanfaatkan hasil hutan, khususnya HHBK perlu didukung, ditindaklanjuti dan diimplementasikan oleh pemerintah daerah (provinsi dan kabupaten) agar tujuan hutan lestari masyarakat sejahtera dapat terwujud.

Strategi ST (Strength-Threath) menghasilkan 4 strategi alternatif, yaitu:

1) melakukan budidaya tanaman jenis-jenis HHBK secara intensif. Strategi ini sangat penting menyangkut upaya memproduksi komoditas HHBK selain dari tegakan alam (kawasan hutan). Dengan adanya usaha budidaya maka jaminan keberlangsungan produksi akan semakin tinggi dan akan mengurangi tekanan terhadap alam (Kementerian Kehutanan, 2010). Diharapkan dengan budidaya HHBK di lahan/kebun milik masyarakat (luar kawasan) dapat dijangkau langsung oleh masyarakat sehingga mempermudah akses ke lokasi sumber HHBK;

2) meningkatkan kapasitas SDM untuk menguasai teknologi budidaya maupun pengolahan HHBK dengan memberikan pelatihan, magang, studi banding, diklat, dan lain-lain. Strategi ini dipandang sangat penting karena untuk meningkatkan kualitas dan kuantitas produk HHBK diperlukan keterampilan dan kapasitas SDM yang memadai, sehingga kegiatan pengembangan HHBK dapat berjalan dengan baik dan lancar;

3) Fasilitasi pembentukan dan penguatan kelembagaan kelompok usaha produsen/ koperasi/asosiasi dalam mengelola HHBK. Usaha pengolahan HHBK yang dilakukan di Kabupaten Minahasa Tenggara lebih banyak dilakukan sendiri-sendiri walaupun sudah ada beberapa kelompok tani, untuk itu strategi ini menjadi sangat penting, karena untuk pengembangan HHBK unggulan sebaiknya dilakukan dalam bentuk kelembagaan yang melibatkan peran serta masyarakat, dengan demikian kepemilikan usaha nantinya adalah masyarakat itu sendiri dalam bentuk kelompok usaha/koperasi/asosiasi; dan
4) peningkatan nilai tambah dan diversifikasi produk HHBK melalui pemberian fasilitasi/bantuan modal usaha, penanganan pasca panen dan pemasaran serta transfer teknologi budidaya dan pengolahan dari hasilhasil penelitian. Strategi ini sangat penting untuk dilakukan, mengingat HHBK merupakan komoditas yang mempunyai nilai ekonomis tinggi dan dapat memberikan nilai tambah sehingga dimasa mendatang cakupan pengusahaan HHBK dapat menunjukkan perkembangan industri tidak hanya bergerak di industri hulu (bahan baku/mentah) tetapi juga meliputi industri tengah (barang setengah jadi) dan hilir (barang jadi atau barang yang siap dipakai oleh konsumen secara langsung). Cakupan di tiga wilayah industri tersebut menunjukkan komoditas tersebut dapat meingkatkan kegiatan ekonomi dan nilai tambah yang tinggi (Kementerian Kehutanan, 2010).

Strategi WT (Weaknesses-Threat) menghasilkan 3 alternatif strategi, yaitu:

1) peningkatan promosi untuk perluasan pemasaran baik di tingkat lokal, nasional maupun internasional. Strategi ini merupakan usaha yang sangat penting dalam mengembangkan HHBK unggulan. Promosi adalah bagian yang penting dalam upaya perluasan pemasaran produk $\mathrm{HHBK}$, mengingat produk-produk HHBK belum terlalu familiar bagi semua orang sehingga perlu dilakukan promosi yang lebih gencar. Hal ini perlu didukung oleh pihak pemerintah baik di tingkat kabupaten, provinsi maupun pusat dan juga pihak swasta;

2) Kebijakan dan sanksi bagi pihak yang melakukan pelanggaran (Penegakkan hukum). Strategi ini merupakan bagian dari pengawasan dan evaluasi untuk memberikan kepastian hukum sebagai bentuk ketegasan akan larangan terhadap pelanggaran yang dilakukan oleh pihak yang bersangkutan.

Berdasarkan kriteria dan indikator penetapan jenis HHBK unggulan, maka dari hasil penelitian ini dirumuskan beberapa strategi pengembangan HHBK unggulan yang dapat diterapkan di KPHP Unit V, yaitu:

1) Aspek Ekonomi: (i) peningkatan kualitas dan diversifikasi produk HHBK;

2) Aspek Biofisik dan Lingkungan: (i) membangun kebun pembibitan HHBK unggulan; (ii) melakukan budidaya tanaman jenis-jenis HHBK secara intensif; dan (iii) perluasan areal tanam jenis HHBK unggulan pada lahan-lahan terbuka dan kritis; 
3) Aspek Kelembagaan; (i) penguatan dan pembinaan kelembagaan kelompok usaha produsen/koperasi/asosiasi dalam mengelola HHBK melalui kegiatan penyuluhan, advokasi, penelitian dan pengembangan (ii) Kebijakan dan sanksi tegas bagi pihak yang melakukan pelanggaran (Penegakkan hukum) dengan tetap mengutamakan pendekatan persuasif kepada masyarakat agar dapat menjaga, memanfaatkan dan melestarikan hutan sesuai aturan dan ketentuan yang berlaku; (iii) dukungan kebijakan (anggaran), pendampingan (teknis dan manajemen) dan fasilitasi (sarana prasarana, modal usaha, penanganan pasca panen dan pemasaran) secara tepat sasaran dari pemerintah daerah;
4) Aspek Sosial; (i) membuka kesempatan bagi pelaku usaha untuk berinvestasi dengan kelompok masyarakat melalui kerjasama yang saling menguntungkan; (ii) mendorong peningkatan akses kelola kawasan kepada masyarakat sekitar hutan lainnya melalui Program Perhutanan Sosial agar ada pemerataan;

5) Aspek Teknologi (i) meningkatkan kualitas dan kapasitas SDM untuk menguasai teknologi budidaya maupun pengolahan HHBK dengan memberikan pelatihan, magang, studi banding, diklat, dan lain-lain.

Tabel 6. Strategi faktor internal dan eksternal dalam Matriks SWOT

\begin{tabular}{|c|c|c|}
\hline Eksternal Factors & $\begin{array}{l}\text { Peluang (Opportunities) } \\
\text { 1. Tingginya permintaan pasar (lokal, nasional dan } \\
\text { internasional) yang cenderung meningkat terhadap } \\
\text { produk olahan HHBK. } \\
\text { 2. Dukungan kebijakan pemerintah bagi pemanfaatan } \\
\text { HHBK di kawasan hutan (Program Perhutanan } \\
\text { Sosial). } \\
\text { 3. Pihak investor mulai tertarik untuk berinvestasi } \\
\text { terhadap produk HHBK sehingga terbuka jaringan } \\
\text { pemasaran ditingkat petani HHBK } \\
\text { 4. Terbukanya peluang untuk meningkatkan nilai } \\
\text { tambah dan diversifikasi produk HHBK unggulan. } \\
\text { 5. Adanya kegiatan pameran yang diselenggarakan } \\
\text { pemerintah untuk mempromosikan produk HHBK } \\
\text { unggulan. } \\
\text { 6. Adanya fasilitasi bantuan pemerintah untuk KTH } \\
\text { melalui Program Perhutanan Sosial (sarana } \\
\text { prasarana pengolahan \& pengembangan HHBK) } \\
\text { dari BPSKL Wilayah Sulawesi. }\end{array}$ & $\begin{array}{l}\text { Ancaman (Threats) } \\
\text { 1. Tingginya kebutuhan hidup menyebabkan } \\
\text { beralihnya status petani HHBK ke tanaman } \\
\text { lain dan atau kegiatan off farm. } \\
\text { 2. Terjadinya kerusakan atau kebakaran hutan } \\
\text { yang terjadi setiap musim kemarau dan } \\
\text { gangguan keamanan dari masyarakat sekitar } \\
\text { hutan di luar KTH. } \\
\text { 3. Terjadinya konflik antar stakeholder dan } \\
\text { disharmonisasi keterlibatan, peran dan } \\
\text { tanggung-jawab stakeholder. } \\
\text { 4. Tuntutan standar mutu ekspor yang tinggi dan } \\
\text { belum tercapainya kestabilan produksi. } \\
\text { 5. Peningkatan persaingan pasar (MEA/AFTA) } \\
\text { dengan adanya produk impor HHBK yang } \\
\text { sudah ada di pasaran. } \\
\text { 6. Terbatasnya dukungan kebijakan (anggaran), } \\
\text { pendampingan (teknis dan manajemen) dan } \\
\text { fasilitasi alat produksi pendukung (sarana } \\
\text { prasarana) dari KPHP Unit V, Pokja PPS dan } \\
\text { Dishutda. }\end{array}$ \\
\hline $\begin{array}{l}\text { Kekuatan (Strength) } \\
\text { 1. Tersedianya potensi jenis dan } \\
\text { jumlah HHBK yang tinggi. } \\
\text { 2. Potensi produksi dan keuntungan } \\
\text { usaha HHBK yang tinggi. } \\
\text { 3. Pemanfaatan dan pengolahan } \\
\text { HHBK yang ramah lingkungan. } \\
\text { 4. Tersedianya benih/bibit unggul lokal, } \\
\text { karena jenis tanaman HHBK mudah } \\
\text { beradaptasi pada berbagai tipe tanah. } \\
\text { 5. Masyarakat sekitar hutan memiliki } \\
\text { askses kelola HHBK di hutan lindung } \\
\text { (IUPHKm). } \\
\text { 6. Tingkat aksesibilitas yang cukup baik } \\
\text { atau sumber HHBK mudah dijangkau } \\
\text { moda transportasi sepanjang tahun. }\end{array}$ & $\begin{array}{l}\text { Strategi S-O } \\
\text { 1. Membangun kebun pembibitan HHBK unggulan } \\
\text { dan perluasan areal tanam jenis HHBK unggulan } \\
\text { pada lahan-lahan kritis. } \\
\text { 2. Mendorong peningkatan akses kelola kawasan } \\
\text { kepada masyarakat sekitar hutan lainnya melalui } \\
\text { Program PS agar ada pemerataan } \\
\text { 3. Pemberian fasilitasi bantuan pemerintah secara tepat } \\
\text { sasaran. } \\
\text { 4. Membuka kesempatan bagi pelaku usaha yang ingin } \\
\text { berinvestasi dengan kelompok masyarakat melalui } \\
\text { kerjasama yang saling menguntungkan. }\end{array}$ & $\begin{array}{l}\text { Strategi S-T } \\
\text { 1. Membina hubungan kemitraan, kooperasi, dan } \\
\text { koordinasi yang baik serta saling memberikan } \\
\text { kontribusi yang bermanfaat diantara stakeholder } \\
\text { dalam pengembangan HHBK unggulan. } \\
\text { 2. Peningkatan kualitas dan kuantitas produk HHBK } \\
\text { sesuai standar mutu ekspor dan menjaga kestabilan } \\
\text { produksi. } \\
\text { 3. Peningkatan kegiatan penyuluhan, komunikasi, } \\
\text { advokasi, penelitian dan pengembangan kepada } \\
\text { masyarakat sekitar hutan dengan pendekatan persuasif } \\
\text { untuk menjaga, memanfaatkan dan melestarikan } \\
\text { hutan. } \\
\text { 4. Memberikan dukungan kebijakan (anggaran), } \\
\text { pendampingan dan fasilitasi dari dari KPHP Unit V, } \\
\text { BPSKL, Pokja PPS dan Dishutda. }\end{array}$ \\
\hline $\begin{array}{l}\text { Kelemahan (Weakness) } \\
\text { 1. Ancaman terhadap populasi jenis HHBK } \\
\text { oleh pemanfaatan/ pemungutan yang } \\
\text { berlebihan. } \\
\text { 2. Teknologi budidaya belum dikuasai oleh } \\
\text { masyarakat. } \\
\text { 3. Teknologi pengolahan, pengemasan \& } \\
\text { pemasaran masih secara tradisional } \\
\text { 4. Manajemen produksi sangat rendah } \\
\text { sehingga kualitas dan kuantitas produk } \\
\text { olahan rendah dan belum stabil. } \\
\text { 5. Belum terbentuknya kelembagaan } \\
\text { kelompok usaha produsen/ koperasi/ } \\
\text { asosiasi. } \\
\text { 6. Skala pemanfaatan yang rendah karena } \\
\text { keterbatasan modal usaha dan sarana } \\
\text { prasarana pengolahan. }\end{array}$ & $\begin{array}{l}\text { Strategi W-O } \\
\text { 1. Melakukan budidaya tanaman jenis-jenis HHBK secara } \\
\text { intensif. } \\
\text { 2. Meningkatkan kapasitas SDM mengusai teknologi budiaya } \\
\text { maupun pengolahan HHBK dengan memberikan pelatihan, } \\
\text { magang, studi banding, diklat, dll. } \\
\text { 3. Fasilitasi pembentukan dan penguatan kelembagaan } \\
\text { kelompok usaha produsen/ koperasi/asosiasi dalam } \\
\text { mengelola HHBK. } \\
\text { 4. Peningkatan nilai tambah dan diversifikasi produk HHBK } \\
\text { dengan memberikan fasilitasi/ bantuan modal usaha, } \\
\text { penanganan pasca panen dan pemasaran serta transfer } \\
\text { teknologi budidaya dan pengolahan dari hasil-hasil } \\
\text { penelitian. }\end{array}$ & $\begin{array}{l}\text { Strategi W-T } \\
\text { 1. Peningkatan promosi untuk perluasan pemasaran baik } \\
\text { di tingkat lokal, nasional maupun internasional. } \\
\text { 2. Kebijakan dan sanksi bagi pihak yang melakukan } \\
\text { pelanggaran (Penegakkan hukum). }\end{array}$ \\
\hline
\end{tabular}

Sumber: Diolah dari Data Primer dan Sekunder (2018) 


\section{KESIMPULAN DAN SARAN}

\section{Kesimpulan}

Kesimpulan dalam penelitian ini adalah bahwa pengembangan HHBK unggulan di Kawasan Hutan Lindung Gunung Soputan KPHP Unit V merupakan hal yang sangat penting untuk diimplementasikan. Pengembangan HHBK dapat dilakukan dengan menggunakan data dan hasil analisa sebagai berikut :

1) Jenis-jenis HHBK yang terdapat di kawasan HL Gunung Soputan, yaitu pinus (Pinus merkusii Jungh et de Virese) dengan potensi komoditi getah pinus, aren (Arenga pinnata Merr) dengan potensi komoditi gula semut, bambu (Bamboo sp.) dengan potensi kerajinan anyaman bambu yang termasuk dalam tingkat keunggulan kelas 2 dan berpotensi untuk dijadikan sebagai produk unggulan daerah; dan kemiri (Aleurites moluccana Wild) dengan potensinya sebagai minyak atstiri yang memiliki tingkat keunggulan kelas 3 .

2) Stakeholder yang terlibat dalam pengeloloaan dan pengembangan HHBK unggulan di kawasan HL Gunung Soputan, adalah sebagai berikut:

a. BPSKL Wilayah Sulawesi, KPHP Unit V dengan tingkat kepentingan (interest) dan pengaruh (influence) yang sangat tinggi, dan Pokja PPS dengan kepentingan yang tinggi namun memiliki tingkat pengaruh yang cukup, termasuk dalam klasifikasi sebagai Key Players (kuadran I);

b. Dinas Kehutanan Daerah Provinsi Sulawesi Utara yang termasuk dalam klasifikasi sebagai Context setters (kuadran II) yaitu stakeholder dengan kepentingan (interest) yang rendah tetapi memiliki pengaruh (influence/power) yang cukup;

c. KTH pemegang IUPHKm dan investor/pelaku usaha yang termasuk dalam klasifikasi sebagai Subjects (Kuadran III) dimana KTH sebagai stakeholder dengan tingkat kepentingan (interest) yang sangat tinggi terhadap kegiatan tetapi memiliki pengaruh (influence) yang rendah, dan investor/pelaku usaha sebagai stakeholder dengan tingkat kepentingan cukup dan memiliki pengaruh yang rendah.

d. Pemerintah desa/kecamatan, pemerintah kabupaten (Dinas Koperasi, UMKM dan Pasar), masyarakat sekitar dan pihak akademisi yang termasuk dalam klasifikasi sebagai Crowd (kuadran IV). Masyarakat sebagai stakeholder dengan tingkat kepentingan (interest) yang cukup dan pengaruh (influence) yang sangat rendah. Pemerintah desa, pemkab (dinas terkait) dan akademisi dengan tingkat kepentingan dan pengaruh yang rendah

3) Strategi pengembangan HHBK unggulan di areal HKm KPHP Unit V yang dapat dilakukan, yaitu:

- peningkatan kuantitas, kualitas dan diversifikasi produk HHBK yang didukung dengan fasilitasi (bantuan sarana prasarana, modal usaha, penanganan pasca panen dan pemasaran) secara tepat sasaran;

- pembangunan kebun bibit, peningkatan budidaya intensif dan perluasan areal tanam jenis HHBK untuk meningkatkan produksi dan kelestarian lingkungan;

- peningkatan kualitas dan kapasitas sumberdaya manusia melalui kegiatan pendampingan, penyuluhan, advokasi, dan pelatihan;

- pemberian kemudahan dan kesempatan bagi bagi pelaku usaha untuk berinvestasi dengan kelompok masyarakat melalui kerjasama yang saling menguntungkan;

- percepatan pemberian akses kelola kawasan kepada masyarakat sekitar hutan lainnya melalui Program Perhutanan Sosial agar ada pemerataan.

\section{Saran}

Berdasarkan kesimpulan di atas, beberapa kegiatan yang menjadi saran dan tindak lanjut kedepan meliputi:

1. Penetapan jenis HHBK unggulan perlu dituangkan dalam bentuk produk kebijakan, seperti Surat Keputusan Gubernur dan/atau Bupati sebagai dasar bagi penyusunan rencana pengembangan HHBK unggulan di wilayah masing-masing.

2. Pengembangan HHBK unggulan melalui Perhutanan Sosial Nusantara (Pesona) di Kabupaten Minahasa Tenggara, khususnya kegiatan Hutan Kemasyarakatan dapat dilakukan dengan memanfaatkan HHBK di kawasan hutan produksi.

3. Perlu dibuat database HHBK yang selalu mutakhir serta dapat dan mudah diakses dengan membuka jaringan kerja (network) untuk menunjang kegiatan pengembangan produksi, usaha dan pemasaran HHBK yang dapat dipusatkan pada sekretariat Pokja Percepatan Perhutanan Sosial.

\section{DAFTAR PUSTAKA}

Anonim. 2018 . Bab II. Gambaran Umum Kondisi Daerah. [Pdf] Rencana Pembangunan Jangka Menengah Daerah Provinsi Sulawesi Utara 2016-2021. Diakses Tanggal 3 Juli 2018 Waktu 20.18.

Anonim. 2018 ${ }^{\mathrm{c}}$. Trading Fact Kontrak Gondorukem Februari 12. [Pdf]. Diakses Tanggal 9 Juli 2018 Waktu 17.00.

Anonim. 2018 . Bab IV. Analisis Sistem. [Pdf] Bogor Agricultural University. Bogor. Diakses Tanggal 2 Maret 2018 Waktu 08.20 Anonim. 2018 a . Bab IV. Metode Penelitian. [Pdf] Bogor Agricultural University. Diakses Tanggal 22 Februari 2018 Waktu 10.12. 
Badan Pusat Statistik Kabupaten Minahasa Tenggara. 2012. Minahasa Tenggara dalam Angka. Kerjasama antara BPS Kabupaten Minahasa Selatan dengan Bappeda Kabupaten Minahasa Tenggara. Katalog BPS:1102001. 7109.

Dinas Kehutanan dan Perkebunan Kabupaten Minahasa Tenggara. 2011. Buku Jilid I Kehutanan - Potensi Kehutanan dan Perkebunan Kabupaten Minahasa Tenggara.

Fahmi, Irham. 2016. Teori dan Teknik Pengambilan Keputusan Kualitatif dan Kuantitatif. Jakarta. PT. Rajagrafindo. ISBN 978-979-769-874-4.

Kadir, W. Abd., San Afri Awang, Ris Hadi Purwanto dan Erny Poedjirahajoe. 2013. Analisis Stakeholder Pengelolaan Taman Nasional Bantimurung Bulusaraung, Provinsi Sulawesi Selatan. Jurnal Manusia dan Lingkungan, Vol. 20, No. 1, Maret. 2013: 11-21. Diakses Tanggal 2 Maret 2018 Waktu 17.20.

Kementerian Kehutanan. 2010. Peraturan Menteri Kehutanan Republik Indonesia Nomor P.21/Menhut-II/2009 Tentang Kriteria dan Indikator Penetapan Jenis Hasil Hutan Bukan Kayu Unggulan. Direktorat Bina Perhutanan Sosial. Jakarta.

Kementerian Lingkungan Hidup dan Kehutanan. 2017. Kumpulan Peraturan Perhutanan Sosial. Direktorat Jenderal Perhutanan Sosial dan Kemitraan Lingkungan Direktorat Penyiapan Kawasan Perhutanan Sosial. Jakarta.

Kusumedi, Priyo, dan Achmad Rizal HB. 2010. Analisis Stakeholder dan Kebijakan Pembangunan KPH Model Maros di Propinsi Sulawesi Selatan. Jurnal Analisis kebijakan Kehutanan. Vol. 7 No. 3, Desember 2010 : 179 -193. Diakses Tanggal 2 Maret 2018 Waktu 17.02

Manullang, Sastrawan. 2018. Teori dan Teknik Analisis Stakeholder. Bogor. IPB Press. Edisi Pertama. ISBN: 978-602-440-204-4.

Nandini, Ryke. 2013. Evaluasi Pengelolaan Hutan Kemasyarakatan (HKm) pada Hutan Produksi dan Hutan Lindungdi Pulau Lombok. Jurnal Penelitian Hutan Tanaman Vol. 10 No. 1, Maret 2013:43-55. ISSN: 1829-6327 Terakreditasi No.: 482/AU2/P2MILIPI/08/2012. Diakses Tanggal 2 Maret 2018 Waktu 16.57.

Nurfatriani, Fitri., Dudung Darusman, Dodik Ridho Nurrochmat, dan Ahmad Erani Yustika. 2015. Analisis Pemangku Kepentingan dalam Transformasi Kebijakan Fiskal Hijau. Jurnal Analisis Kebijakan Kehutanan Vol. 12 No. 2, Agustus 2015 : 105 - 124. Diakses Tanggal 2 Maret 2018 Waktu 17.02 .
Oktadiyani, Poppy., Iwanuddin dan Helwinsyah. 2015. Strategi Pengembangan Priwisata Alam Taman Wisata Alam Wera. Jurnal Wasian Vol. 2 No. 1, Maret 2015, Hal. 0920. ISSN 2355-9969.

Sembiring, Edward., Sambas Basuni, dan Rinekso Soekmadi. 2010. Resolusi Konflik Pengelolaan Taman Nasional Teluk Cenderawasih di Kabupaten Teluk Wondama. JMHT Vol. XVI, (2): 84-91, Agustus 2010. Artikel Ilmiah ISSN: 20870469. Diakses Tanggal 22 Februari 2018 Waktu 09.59.

Suhesti, Eni., Hadinoto, dan Muhammad Ikhwan. Strategi Pengembangan Hasil Hutan Bukan Kayu Unggulan di Kabupaten KamparRiau. 2017. Wahana Forestra: Jurnal Kehutanan. Vol. 12, No. 1. Januari 2017. Diakses Tanggal 1 Maret 2018 Waktu 16.57.

Wahyudi. 2013. Buku Pegangan Hasil Hutan Bukan Kayu.[Pdf]. Yogyakarta. Pohon Cahaya. Diakses Tanggal 14 Desember 2017 Pukul 14.54.

Wibawa, Sutrisna. 2013. Strategi Pengembangan Bisnis Melalui Analisis SWOT. Disampaikan dalam Bimbingan Teknis Peningkatan Kapasitas UKM Tenant Inkubator Bisnis ke-3 untuk UMKM. Inkubator Bisnis PSW/G Bekerjasama dengan Kementerian Koperasi dan UKM, Lembaga Penelitian dan pengambdian kepada Masyarakat Universitas Negeri Yogyakarta. Yogyakarta, 3 Juli 2013. Diakses Tanggal 2 Maret 2018 Waktu 16.52 .

Wibowo, Gatot Dwi Hendro. 2013. Analisis Kebijakan Pengelolaan Hasil Hutan Bukan Kayu (HHBK) di NTB dan NTT. Jurnal Hukum dan Pembangunan Tahun ke-43 No. 2 April-Juni 2013. Diakses Tanggal 2 Maret 2018 Waktu 16.57.

Wiratno. 2014. Kebijakan Pemanfaatan Hasil Hutan Bukan Kayu dalam Rangka Kelola Kawasan untuk Kesejahteraan Rakyat. Disampaikan pada Seminar Nasional "Peranan dan Strategi Kebijakan Pemanfaatan Hasil Hutan Bukan Kayu (HHBK) dalam Meningkatkan Daya Guna Kawasan (Hutan). University Club, Universitas Gadjah Mada, Yogyakarta 6-7 November 2014. Diakses Tanggal 4 Maret 2018 Waktu 17.24. 